\title{
Reproductive biology of the bushmaster Lachesis muta (Serpentes: Viperidae) in the Brazilian Atlantic Forest
}

\author{
Fátima Q. Alves ${ }^{1}$, Antônio J. S. Argôlo², and Gilson C. Carvalho ${ }^{3}$ \\ ${ }^{1}$ CEPEC/CEPLAC, Rod. Ilhéus/Itabuna, Km 22, Caixa Postal 7, 45600-000, Itabuna, BA, Brazil. \\ E- mail: queirozalves@gmail.com. \\ ${ }^{2}$ UESC - Departamento de Ciências Biológicas. Rodovia Jorge Amado, km 16, Bairro Salobrinho, Ilhéus, BA, Brazil. \\ 45662-900. E-mail: ajargolo@gmail.com. \\ ${ }^{3}$ Departamento de Biointeração, ICS. Universidade Federal da Bahia - UFBA, BA, Brazil. E-mail: biogilson@gmail.com.
}

\begin{abstract}
Reproductive biology of the bushmaster Lachesis muta (Serpentes: Viperidae) in the Brazilian Atlantic Forest. The Neotropical genus Lachesis Daudin, 1803 includes snakes restricted to the humid forests of Central and South America. The species L. muta is the most widely dispersed, occurring throughout the Amazon rainforest, and with an isolated population in the Atlantic Forest, from the north of the state of Ceará to the south of the state of Rio de Janeiro, Brazil. We present information about the reproductive biology of L. muta from a large series of samples gathered in southern Bahia. Mature males L. muta are larger than females. Degree of sexual size dimorphism (SSD) is 0.16 . Vitellogenic follicles and eggs are not distributed equally throughout the year. Clutch size was 3-14 oviductal eggs and was positively correlated with female SVL. Testes volume and ductus deferens diameter in mature individuals did not vary significantly throughout the year. The reproductive pattern of $L$. muta differs from that of the phylogenetically related genera because $L$. muta is oviparous, and has a discontinuous cycle and reproductive synchrony between the sexes.
\end{abstract}

Keywords: fecundity, oviparity, reproductive cycle, South America.

\footnotetext{
Resumo

Biologia reprodutiva da surucucu Lachesis muta (Serpentes: Viperidae) da Floresta Atlântica brasileira. O gênero Neotropical Lachesis Daudin, 1803 inclui serpentes restritas às florestas úmidas da América do Sul e Central. A espécie Lachesis muta é mais amplamente distribuída, ocorrendo em toda a Floresta Amazônica e com uma população isolada na Mata Atlântica, desde o norte do estado
}

Received 10 June 2014.

Accepted 24 November 2014.

Distributed December 2014. 
do Ceará, ao sul do estado do Rio de Janeiro, Brasil. Apresentamos informações sobre a biologia reprodutiva de L. muta a partir da análise de uma grande série de amostras recolhidas no sul da Bahia. Os machos maduros de L. muta foram maiores que as fêmeas. O grau de dimorfismo sexual (SSD) foi 0,16. Folículos vitelogênicos e ovos não foram distribuídos homogeneamente ao longo do ano. O tamanho da ninhada foi 3-14 ovos e positivamente correlacionado com o CRC das fêmeas. O volume testicular e o diâmetro dos ductos deferentes nos indivíduos maduros não apresentaram variação significativa ao longo do ano. O padrão reprodutivo de $L$. muta difere daquele de gêneros filogeneticamente relacionados, pois essa espécie é ovípara, tem ciclo descontínuo e sincronia reprodutiva entre os sexos.

Palavras-chave: América do Sul, ciclo reprodutivo, fecundidade, oviparidade.

\section{Introduction}

The Neotropical genus Lachesis Daudin, 1803 includes snakes restricted to the humid forests of Central and South America (Vial and Porras-Jímenez 1967, Campbell and Lamar 2004). The four recognized species (Campbell and Lamar 2004, Fernandes et al. 2004) occur in relatively restricted regions. Lachesis stenophrys occurs on the Atlantic slope of Costa Rica, Panama, and possibly southern Nicaragua. Lachesis melanocephala occupies southwestern Costa Rica and possibly occurs in the western part of Panama on the Pacific slopes and Lachesis achrochorda is distributed on both the Atlantic and Pacific slopes of eastern Panama, northwestern Colombia (Atlantic coast) to northwestern Ecuador. The fourth species, Lachesis muta, is the most widely distributed, occurring in the equatorial forests of Brazil, Venezuela, Trinidad, Guyana, Suriname, French Guiana, Ecuador, Peru, and Colombia, in addition to an isolated population located in the Atlantic Forest, from the north of the state of Ceará to the south of the state of Rio de Janeiro (Campbell and Lamar 2004).

Lachesis, which can exceed $3 \mathrm{~m}$ in length, is the largest known viperid (Campbell and Lamar 2004). Except for Bothrocophias colombianus, they also are the only egg-laying viperids in the Neotropics (Greene and Santana 1983, Campbell and Lamar 2004). Observations made on captive, as well as wild Lachesis, suggest that these vipers protect their clutches (Ripa 1994, Melgarejo et al. 1999, Campbell and Lamar 2004, Souza 2007). Despite the peculiar biological attributes of Lachesis, the little information that exists about reproduction in the genus mainly is based on captive Central American species (Campbell and Lamar 2004 and related work). In Brazil, publications on the ecology of L. muta focus on the Amazonian populations (Beebe 1946, Cunha and Nascimento 1978, 1993), and the scarce information available on the breeding populations in the Atlantic Forest references records of oviparity in species (Amaral 1926) and births in captivity (Campbell and Lamar 2004, Souza 2007).

It is important to document the reproductive biology of the population of Lacheis muta in the Atlantic Forest because this population was listed as vulnerable by the IUCN (2012) owing to habitat loss caused by the massive destruction of this ecosystem; currently, only $78 \%$ of the original area remains intact. Recently, experts asserted that this species is endangered in Bahia as a result of habitat restrictions (A. J. S. Argôlo 2014, pers. comm.). Thus, populations of $L$. muta inhabiting these forest fragments are at risk for survival because of their isolation. Reproductive studies of these oviparous viperids are critical to formulate successful strategies for captive management and species conservation in situ. 
Nearly all Neotropical snake reproductive studies are based primarily on the morphology of the gonads (Zug et al. 1979, Pizzatto and Marques 2002, Pinto and Fernandes 2004, Alves et al. 2005, Marques and Muriel 2007). In males, gonadal variation can only be assessed by histological examination of the testis and deferens duct (Mathies 2011). Herein we present the first information about the reproductive biology of L. muta from regions of south of Bahia, based on morphological and histological techniques.

\section{Materials and Methods}

We examined 139 specimens (Appendix I) of Lachesis muta that were killed between 1989 and 2007 in farming areas in a strip of the Atlantic Forest in southern Bahia and subsequently sent to the Coleção Zoológica Gregório Bondar (CZGB) of the Museu de Zoologia da Universidade Estadual de Santa Cruz (MZUESC) in Ilhéus, Bahia, Brazil. The climate in the study region is Type Af (Koeppen 1948) -i.e., hot and humid, without a wellmarked dry season (Roeder 1975).Winter (JuneSeptember) temperatures average $18^{\circ} \mathrm{C}$ and summer (December-March) temperatures average $26^{\circ} \mathrm{C}$. The average annual temperature is $26^{\circ} \mathrm{C}$. The humidity reaches $78 \%$ and exceeds $80 \%$ near the coast. Rain falls throughout most of the year, but it is concentrated from March-August. The annual average rainfall is $1500 \mathrm{~mm}$, but can be as much as $2000 \mathrm{~mm}$ near the coast owing to high temperature, humidity, and condensation (Sá et al. 1987).

The following variables were measured in each specimen: (1) head diameter (HD); (2) head length (HL, measured with calipers); (3) snoutvent length (SVL); (4) tail length (TL) (measured with measuring tape in $\mathrm{mm}$ ); (5) largest and smallest testicle diameter (e.g., Saint Girons 1982); (6) ductus deferens diameter in three regions (proximal, middle and distal); (7) diameter of the largest follicle and egg (measured with calipers); (8) number of follicles and eggs in the oviducts; and (9) reproductive condition (recorded as mature or immature). Testicular volume was calculated using the ellipsoid volume formula $\mathrm{TV}=4 \pi / 3 \mathrm{ab}^{2}$, where $\mathrm{a}=$ largest radius, and $b=$ smallest radius (see James and Shine 1985). We used " $t$-tests" to compare the SVL and TL of males and females.

We considered mature males those with enlarged testes, and opaque and convoluted ductus deferens, indicating the presence of sperm (Shine 1977a,b, 1980, 1982) and mature females those with vitellogenic follicles or mature oviducts (Shine 1987). The developmental stages of follicles were based on those of Dessauer and Fox (1959), Aldridge (1979) and Zug et al. (1979). Because the oviducts vary during the breeding season (e.g., Dessauer and Fox 1959, Fox1956, Blackburn 1998, Janeiro and Cinquini 2004), their condition could be used to infer maturity.

The analysis of the female reproductive cycle was based on the number of mature females collected each month, and the number of females with vitellogenic follicles or eggs in the same period, using the Kruskal-Wallis test. The male reproductive cycle was inferred through an ANOVA that evaluated the diameter of the ductus deferens and the residuals resulting from the regression of the SVL and the testicular volume each month.

Reproductive organs were prepared histologically and examined under a light microscope to complete our morphometric data. Three females with vitellogenic follicles, and one or two mature males were examined each month. We removed the distal region of the ductus deferens and the distal lobe of the right testicle, and the posterior oviduct and vagina in females. The oviduct was divided into the vagina, posterior and anterior uterus, and infundibulum (e.g., Blackburn 1998). The preparation of tissues for a histological analysis of testicles, deferens duct, and oviducts followed routine histological techniques (Kiernan 1990). Sections of $7 \mu \mathrm{m}$ were made and stained with Harris hematoxylin and eosin. Light microscopy was 
used to detect the presence of sperm in the oviducts and vagina of females. The spermatogenetic stages were classified according to Goldberg and Parker (1975). The type of reproductive cycle was characterized according to Saint-Girons (1982) and Mathies (2011).

Egg laying, hatching periods, clutch size, and SVL of hatchlings were obtained from preserved specimens, and from eggs and newborns observed in nature. We used correlation analyses to relate female SVL with clutch size and female SVL with the diameter of the follicles and egg length. We include numeric size instead of clutch mass because we were unable to remove the oviductal eggs of museum specimens.

Degree of sexual size dimorphism (SSD) was calculated by dividing the mean adult SVL of the larger sex by the mean adult SVL of the smaller sex minus 1 (Shine 1994). All tests were performed using Statistica software (Ver. 8.0), assuming $p<0,05$ for significance.

\section{Results}

\section{Sexual Maturity and Body Size}

The smallest mature female has a SVL of $1118 \mathrm{~mm}$, whereas the SVL of the smallest mature male is $1292 \mathrm{~mm}$. Mature female SVL ranges from $1118-2200 \mathrm{~mm}($ mean $=1604.61 \pm$ $318.97, N=65$ ), and TL from $55-180 \mathrm{~mm}$ $($ mean $=136.87 \pm 20.48, N=65)$. Mature male SVL ranges from 1292-2375 $\mathrm{mm}$ (mean = $1731.20 \pm 389.66, N=74$ ), and TL from $55-$ $180 \mathrm{~mm}$ (mean $=150.37 \pm 22.18, N=74)$. Mature female SVL $(t=3.95 ; p<0.0492)$ and TL $(t=2.4 p<0.0006)$ is significantly shorter male SVL. The degree of sexual size dimorphism (SSD) is 0.16 .

\section{Female Reproductive Cycle}

Vitellogenic follicles and eggs do not vary significantly during the year (Kruskal-Wallis test $=5.6404 ; p=0.8962 ;$ Figure 1$)$. We observed females with vitellogenic follicles from April-
August (fall/winter) and in December (late spring and early summer); follicles in primary vitellogenesis were observed from January-April (between summer and fall) and OctoberNovember (spring), and follicles in secondary vitellogenesis from June-July (late fall and early winter), and in December at the beginning of summer. We observed as many as 48.22 \pm 5.67 $\mathrm{mm}$ in March $(N=1)$, August $(N=2)$, September $(N=3)$ and December $(N=1)$, summer, winter, and spring respectively and shelled oviductal eggs in January $(N=3)$, November $(N=1)$ and December $(N=1)$.

We collected a female (CZGB 3123) with 14 developing eggs in her oviducts in August 1994. A second female (CZGB 6669) was captured in October 1995 with another individual (possibly a male); these snakes were held in captivity, and the female laid nine eggs on the $8^{\text {th }}$ and $9^{\text {th }}$ of January 1996. Following incubation, the eggs produced seven hatchlings. We captured another female (CZGB 8041) in October 1998 and held her captive; she laid six eggs on 30 November 1998. One egg was stuck near the cloaca and removed on 4 December 1998; three other eggs remained in the oviduct.

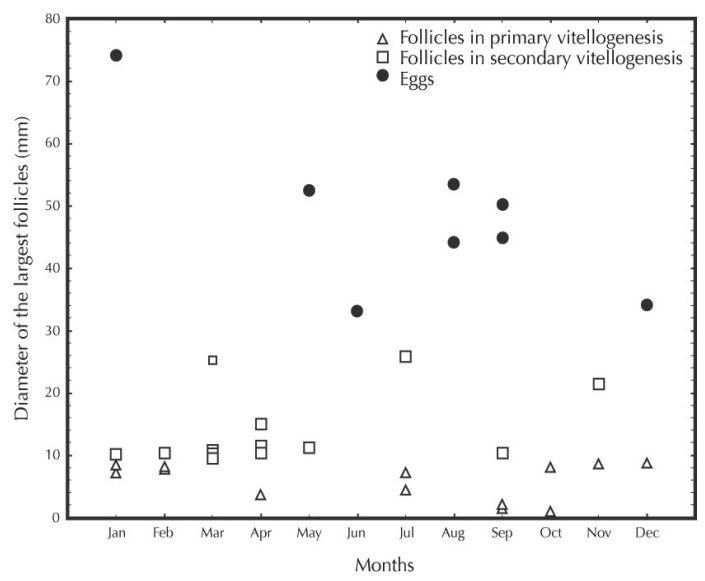

Figure 1. Seasonal variation in the diameter of the largest ovarian follicles and eggs in adult females (SVL $\geq 1118 \mathrm{~mm}$ ) of Lachesis muta. 
We collected eggs and hatchlings in the wild from January-April and young $(\mathrm{SVL}<500 \mathrm{~mm}$; average size of a hatchling) from March-June. These dates indicate that oviposition occurs in the summer and early fall.

Light microscopy of a female (CZGB 7354) captured in early winter (June) with follicles in secondary vitellogenesis revealed no sperm in the posterior region of the uterus. Females (CZGB 299 and 2965) killed in late summer (March) and early fall (April) with follicles in primary vitellogenesis also lacked sperm in the vagina or in the posterior end of the uterus (Figure 2).

\section{Fecundity}

Lachesis muta clutch sizes are 3-14 eggs $(5.83 \pm 1.48 ; N=12)$ and not positively correlated with female SVL $\left(r^{2}=0.0172 ; p=\right.$ $0.5146)$. Egg length is $64.07 \pm 21.2 \mathrm{~mm}(44.2-$ $92.5 \mathrm{~mm}, N=54$ eggs from 12 clutches, from dissected specimens). The largest follicle measured was $34.3 \mathrm{~mm}$ and the smallest egg was $44.2 \mathrm{~mm}$. Female SVL is significantly correlated

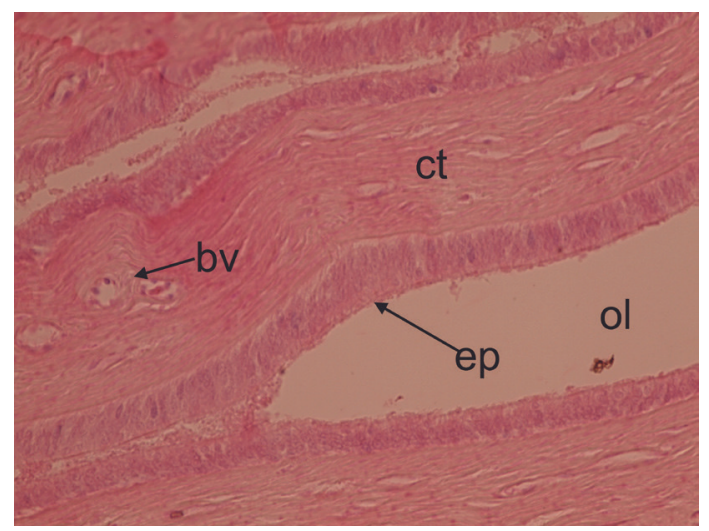

Figure 2. Transverse paraffin sections of the vagina of Lachesis muta in the early winter. ep: epithelium; ct: connective tissue; ol: oviductal lumen; bv: blood vessels. with the diameter of the follicles and with egg length $\left(r^{2}=0.207, p=0.0047, N=55\right)$. The hatchlings are $505 \pm 14.4 \mathrm{~mm}(492-614, N=11)$ long, approximately $31.5 \%$ of maternal SVL.

\section{Male Reproductive Cycle}

The testicular volume $(F=0,84887, p=$ 0,58017, $N=60$; Figure 3) and deferens duct diameter in mature individuals $(F=0,68370, p=$ $0,71692, N=60$ ) shows no significant variation during the year.

The light microscopic examinations revealed that in the summer, the germinal epithelium of seminiferous tubules is large (Figure 4A) and in spermiogenesis. At the end of summer, starts the recrudescence phase begins (Figure 4B) and continues throughout the fall. During this period two or three layers of cells are present (mainly spermatogonia) and the tubule lumen becomes empty. In the winter (Figure 4C, D), the epithelium of the seminiferous tubules undergoes spermiogenesis and in late spring, recrudescence occurs. Deferens ducts contain spermatozoa in all seasons (Figure 4E).

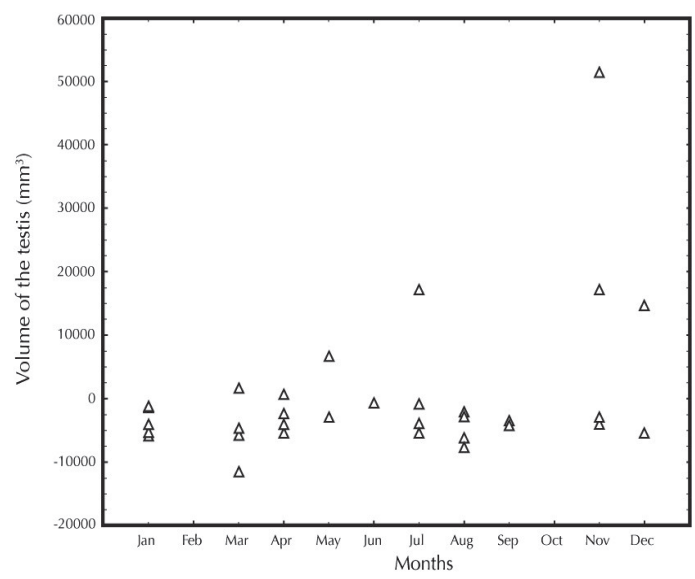

Figure 3. Relative volume of the testes in mature males of Lachesis muta throughout the year. 
Alves et al.
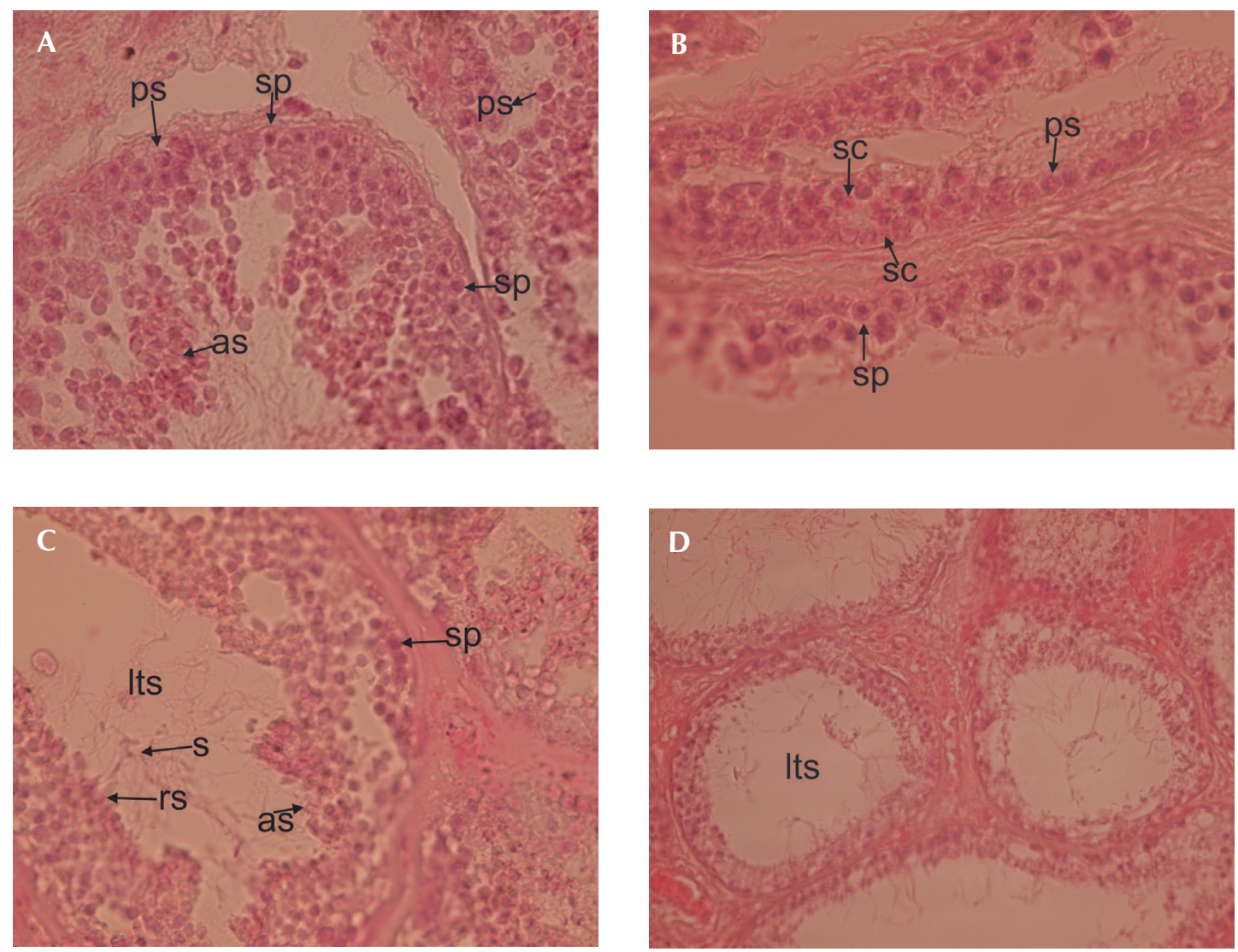

Figure 4. Transverse and sagittal paraffin sections throught the testis and ductus deferens of Lachesis muta. In the summer (A), the germinal epithelium of seminiferous contains spermatagonias, primary spermatocytes, spermatids in spermiogenesis, Sertoli cells, spermatozoa is present in the lumen of the seminiferous tubules. But during autumn remains in regression $(\mathbf{B})$. In winter $(\mathbf{C}, \mathbf{D})$, the epithelium presents some spermatogonia, many round and elongated spermatids, and spermatozoa released in the lumen of the seminiferous tubules. During spring (E) we observed primary and secondary spermatocytes in the germinal epithelium, and spermatozoa released in the lumen of the seminiferous tubules. sp: spermatogonia; ps: primary spermatocytes; ss: secundary spermatocytes; as: elongated spermatids; rs: round spermatid; s: spermatozoa; sc: Sertoli cells; Ist: lumen of seminiferous tubules.

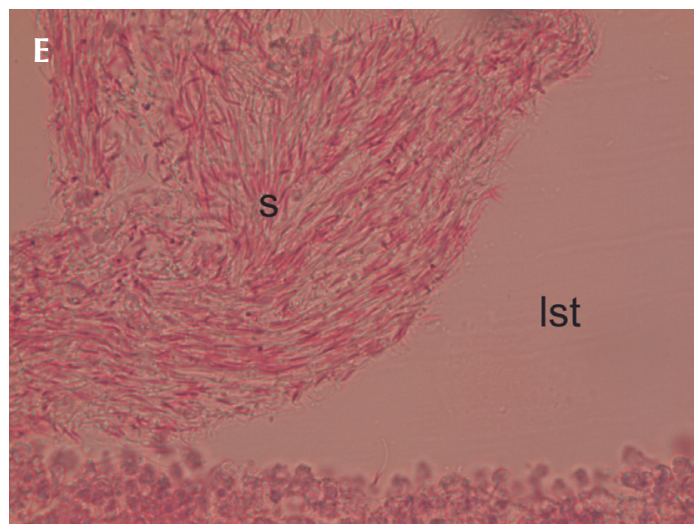




\section{Discussion}

In many ophidian species, females are larger than males (Shine 1994, 2003, Hartmann et al. 2004, Alves et al. 2005). However, unlike other viperids (Solorzano and Cerdas 1989, Hartmann et al. 2004), male Lachesis muta are longer than females. Larger body size is advantageous for males in species that perform ritual combat during courtship to determine dominant relationships (Shine 1978, 1994, 2003). Possible ritual combat has been observed among males of L. melanocephala (Ripa 1994). According to the author, combat does not seem to be necessary to encourage sexual activity in the male. The degree of sexual dimorphism observed in the present study is less than 0.25 , and snakes with this pattern demonstrate combat between males (Shine 1994).

With regard to clutch size, Melgarejo et al. (1999) recorded 15 and 13 eggs in two clutches from the same captive female of Lachesis muta from the state of Alagoas. Boyer et al. (1989) reported 10 eggs in a captive female of $L$. muta from Trinidad. Ripa (1994, 2004) studied litters of 13 and 16 eggs in L. melanocephala and $L$. stenophrys, respectively, held in captivity, and Chacon and Valverde (2004) reported $L$. stenophrys to have laid 11 eggs within 3 mo of having been captured in the wild. According to Campbell and Lamar (2004), the average litter size in Lachesis probably is 6-11 eggs. Based on a larger sample, the present study reported clutches from 3-14 eggs in the L. muta population of southern Bahia, with an average of 5.83 eggs per clutch; this average is not correlated to the female SVL. This pattern may be related to the fact that female $L$. muta mature with a smaller SVL than that of the male, and according to Shine (2003), female body size determines clutch mass only if the snake delays reproduction until it reaches a larger body size.

A contrasting pattern has been observed in species in which mature females are longer than males (e.g., Shine 1994, Pizzatto 2002, Hartmann et al. 2004, Alves et al. 2005, Pleguezuelos et al.
2007, Pinto et al. 2010) because larger body size confers a selective advantage for the female by increasing her ability to contain eggs or neonates (Shine 1994, 2003). Although the fecundity of females could be determined by the stored energy (body fat), we did not analyze the correlation between corporeal mass and litter size. However,we found (unpubl. data) the five levels of abdominal fat (classification proposed by Pleguezuelos and Feriche 2006) in the females at all stages of vitellogenesis and containing oviductal eggs.

With respect to egg size, Carrillo (1970) reported that the eggs of Peruvian Lachesis muta are as large as $10 \mathrm{~cm}$ long. The maximum size of $92.5 \mathrm{~mm}$ that we recorded exceed that of $L$. melanocephala (88 mm) (Ripa 1994, 2004), L. stenophrys (76 and $79.9 \mathrm{~mm}$ ) (Ripa 1994, 2004, Chacon and Valverde 2004), and L. muta from the Atlantic Forest $(69.9 \mathrm{~mm})$ (Melgarejo et al. 1999). The egg length in L. muta is not positively correlated with female SVL.

The reproductive strategy of Lachesis muta in the Atlantic Forest of southern Bahia encompasses a seasonal reproductive cycle. Mating can occur in winter and summer, once we find follicles in secondary vitellogenesis in fall, winter and summer, and eggs in the summer, winter and spring. Light microscopy of the posterior oviduct revealed no sperm in the vagina of CZGB 7354, which was in secondary vitellogenesis in early winter, and CZGB 299 and 2965, which were in primary vitellogenesis in late summer. However, our data are insufficient to infer that female L. muta store sperm.

Oviposition occurs mostly from NovemberFebruary, the warmest time of the year and the most suitable for embryonic development, whereas births occur from January-April, between the hottest period and the beginning of the season with the greatest concentration of rain. The only two published records of copulation and oviposition in this species are consistent with our data. From one female (not 2, as reported in Campbell and Lamar 2004) captured in the state of Alagoas, Melgarejo et al. 
(1999) recorded mating on 22 August and egglaying on 06 December 1995. In Itacaré, Souza (2007) studied a pair in copulation in September and subsequent oviposition in December. Although the annual temperature variation in the Atlantic Forest of southern Bahia falls within a range of $7^{\circ} \mathrm{C}$ and rainfall is distributed throughout most of the year (e.g., Sa et al. 1987), oviposition and births of Lachesis muta are concentrated in the warmer months, whereas secondary vitellogenesis and spermatogenesis occur in the colder months, demonstrating determined seasonality in the reproductive cycle of the species. These data agree with those postulated by Mathies (2011), and contradict those assumed by Souza (2007) for L. muta .

With respect to congeners of Lachesis muta, nothing is known about $L$. acrochorda reproduction; however, mating in captivity by $L$. stenophrys and L. melanocephala was recorded in January, February, and March, with oviposition in May and births in July (Ripa 1994, 2004). In Costa Rica, Chacon and Valverde (2004) recorded L. stenophrys laying eggs in August and births occurring in November. Although these records are insufficient for us to ascertain the reproductive cycle of these species, the month for births falls during the rainy season in Central America where the species occur.

The length of the mating season and the timing of egg laying and births, as well as others features, may be related to the local environment of Lachesis muta in the same way as it is in other tropical snakes (e.g., Vitt and Vangilder 1983). In Bothrops pubescens, a viviparous viperid in southeast Brazil, the reproductive cycle also is related to warmer periods of the year (Hartmann et al. 2004), although the seasons in this region are more distinct. In tropical Colubridae (Pizzatto and Marques 2002, Pinto et al. 2010) and Elapidae (Marques 1996b), which have seasonal reproductive cycles, the breeding season is concentrated in the hot, rainy months.

Testicular volume is lower between January and April-i.e., the time for births, when there is no courtship activity. In contrast, testicular volume increases in winter and summer during the peak of vitellogenesis in females. Spermatogenesis corresponds to an increase in testicular volume, with a peak in the coldest period of the year (June) and another in the summer (January), demonstrating synchrony between secondary vitellogenesis in females and spermatogenesis in males. The timing of vitellogenesis and spermatogenesis relative to the mating period between winter and early summer suggests that the reproductive cycle in Lachesis muta should be classified as pre-nuptial (Saint-Girons 1982). However, according to the recent classification of the reproductive cycles of tropical snakes (Mathies 2011), the cycle in L. muta is discontinuous. Owing to the synchrony of the mating season and spermatogenesis, perhaps male $L$. muta have no need to store sperm.

According to the most recent phylogeny of Viperidae (e.g., Gutberlet and Harvey 2004, Castoe and Parkinson 2006), Lachesis is closely related to Bothrocophias and Bothrops (sensu Carrasco et al. 2012). The reproductive cycles of several species of Bothrops shows marked seasonality, with variations conditioned by climate (e.g., Schuett 1992; Solorzano and Cerdas 1986, Alves et al. 1998, Alves et al. 2000, Hartmann et al. 2004, Almeida-Santos and Solomão 2002). The reproduction pattern of $L$. muta differs from those related taxa in having discontinuous cycles, reproductive synchrony between the sexes, and being oviparous.

\section{Acknowledgments}

We would like to thank Guisla Boehs for access to the Laboratório de Histologia Animal of the Universidade Estadual de Santa Cruz, Mariane Aguiar for her help in preparing the histological slides, Linda Trueb for valuable comments on the manuscript and English review, Marcos F. Vila Nova for his help in the selection of specimens and José Montival Alencar Jr. and Alvaro Coelho B. de Alencar for assisting with the figures. 


\section{References}

Aldridge, R. D. 1979. Female reproductive cycles of the snakes Arizona elegans and Crotalus viridis. Herpetologica 35: 256-261.

Almeida-Santos, S. M. and M. G. Salomão. 2002. Reproduction in Neotropical pitvipers, with emphasis on species of the genus Bothrops. Pp. 307-328 in G. Schuett, M. Höggren, and H. W. Greene (eds.), Biology of the Vipers. Utah. Eagle Mountain Publishing.

Almeida-Santos, S. M., I. L. Laporta-Ferreira, M. M. Antoniazzi, and C. Jared. 2004. Sperm storage in males of the snake Crotalus durissus terrificus (Crotalinae: Viperidae) in southeastern Brazil. Comparative Biochemistry. Physiology. Part A: Molecular and Integrative Physiology 139: 169-174.

Alves, M. L. M., M. L. Araujo, and E. Caberlon. 1998. Atividade reprodutiva de Bothrops neuwiedi em cativeiro (Serpentes, Viperidae). Iheringia, Série Zoologia 84: 185-191.

Alves, M. L. M., M. L. Araujo, and A. A. Witt. 2000. Aspectos da biologia reprodutiva de Bothrops jararaca em cativeiro (Serpentes, Viperidae). Iheringia, Série Zoologia 89: 187-192.

Alves, F. Q., A. J. S. Argolo, and J. Jim. 2005. Biologia reprodutiva de Dipsas neivai Amaral e D. catesbyi (Sentzen) (Serpentes, Colubridae) no sudeste da Bahia, Brasil. Revista Brasileira de Zoologia 22: 573-579.

Amaral, A. 1926. On the oviparity of Lachesis muta Daudin, 1803. Copeia 149: 93-94.

Beebe, W. 1946. Field notes on the snakes of Kartabo, British Guiana, and Caripito, Venezuela. Zoologica 31: $11-52$.

Blackburn, D. G. 1998. Structure, function and evolution of the oviducts of squamate reptiles, with special reference to viviparity and placentation. Journal of Experimental Zoology 282: 560-617.

Boyer, D. M, L. A. Mitchell, and J. B. Murphy. 1989. Reproduction and husbandry of the Bushmaster Lachesis muta muta at the Dallas Zoo. International Zoo Yearbook 28: 190-194.

Campbell, J. A. and W. W. Lamar. 2004. The Venomous Reptiles of the Western Hemisphere. Vol. I. Ithaca. Comstock Publishing Associates. 976 pp.

Carrasco, P. A., C. I. Mattoni, G. C. Leynaud, and G. J. Scrocchi. 2012. Morphology, phylogeny and taxonomy of South American bothropoid pitvipers (Serpentes, Viperidae). Zoologica Scripta 41: 109-124.
Carrillo, D. E. 1970. Contribución al conocimiento de los reptiles del Perú. Publicaciones del Museo de Historia Natural Javier Prado. Serie A. Zoologia 22: 1-64.

Castoe, T. A. and C. L. Parkinson. 2006. Bayesian mixed models and the phylogeny of pitvipers (Viperidae, Serpentes). Molecular Phylogenetics and Evolution 39: 91-110.

Chacon, D. and D. Valverde. 2004. Lachesis stenophrys (Bushmaster). Reproduction. Herpetological Review 35: 68.

Cunha, O. R. and F. P. Nascimento. 1978. Ofídios da Amazônia X. As cobras da região leste do Pará. Boletim do Museu Paraense Emílio Goeldi 31: 1-218.

Cunha, O. R. and F. P. Nascimento. 1993. Ofídios da Amazônia. As cobras da região leste do Pará. Boletim do Museu Paraense Emílio Goeldi 9: 1-191.

Dessauer, H. C. and W. Fox. 1959. Changes in ovarian follicle composition with plasma levels of snakes during estrus. American Journal of Physiology 197: 360-366.

Fernandes, D. S., F. L. Franco, and R. Fernandes. 2004. Systematic revision of the genus Lachesis Daudin, 1803 (Serpentes, Viperidae). Herpetologica 60: 245-260.

Fitch, H. S. 1982. Reproductive cycles in tropical reptiles. Occasional Papers of the Museum of Natural History, University of Kansas 96: 1-53.

Fox, W. 1956. Seminal receptacles of snakes. Anatomical Record 124: 519-540.

Gutberlet, R. L. and M. B. Harvey. 2004. Phylogenetic relationships of new world pitvipers as inferred from anatomical evidence. Pp. 51-68 in G. Schuett, M. Höggren, and H. W. Greene (eds.), Biology of the Vipers. Utah. Eagle Mountain Publishing.

Greene, H. W and M. A. Santana. 1983. Field studies of hunting behavior by bushmasters. American Zoologist 23: 897.

Goldberg, S. R. and W. S. Parker. 1975. Seasonal testicular histology of the colubrid snakes, Masticophis taeniatus and Pituophis melanoleucus. Herpetologica 31: 317-322.

Hartmann, M. T., O. A. V. Marques, and S. M. AlmeidaSantos. 2004. Reproductive biology of the southern Brazilian pitviper Bothrops pubescens (Serpentes, Viperidae). Amphibia-Reptilia 25: 77-85.

IUCN. 2014. IUCN Red List of Threatened Species. Version 2012.2. Electronic Database accessible at http://www. iucnredlist.org. Captured on 29 January 2014. 
James, C. and R. Shine. 1985. The seasonal timing of reproduction: a tropical-temperate comparison in Australian lizards. Oecologia 67: 464-474.

Janeiro-Cinquini, T. 2004. Variação anual do sistema reprodutor de fêmeas de Bothrops jararaca (Serpentes, Viperidae). Iheringia, Série Zoologia 94: 325-328.

Jones, R. E., R. R. Tokarz, F. T. LaGreek, and K. T. Fitzgerald. 1976. Endocrine control of clutch size in reptiles: VI. Patterns of FSH-induced ovarian stimulation in adult Anolis carolinensis. General and Comparative Endocrinology 30: 101-116.

Koeppen, W. 1948. Climatología: con un estudio de los climas de la Tierra. México. Fondo de Cultura Económica. 478 pp.

Kiernan, J. A. 1990. Histological and Histochemical Methods: theory and practice. New York. Pergamon Press. 513 pp.

Marques, O. A. V. 1996. Reproduction, seasonal activity and growth of the coral snake, Micrurus corallinus (Elapidae), in the southeastern Atlantic Forest in Brazil. Amphibia-Reptilia 17: 277-285.

Marques, O. A. V. and A. P. Muriel. 2007. Reproductive biology and food habitats of the swamp racer snake Mastigodryas bifossatus (Colubridae) from southeastern South America. Journal of Herpetology 17: 104-109.

Mathies, T. 2011. Reproductive cycles of tropical snakes. Pp. 511-550 in R. D. Aldridge and D. M. Sever (eds.), Reproductive Biology and Phylogeny of Snakes. Boca Raton. CRC Press.

Melgarejo, A. R., A. C. M. Cunha, and Aguiar A. S. 1999. Reprodução de Lachesis muta rhombeata Wied, 1824 (Serpentes: Viperidae). V Congreso Latinoamericano de Herpetología. Montevideo, Uruguay. Publicación extra, Museo Nacional de Historia Natural.

Pleguezuelos, J. M., X. Santos, J. C. Brito, X. Parellada, G. A. Llorente, and S. Fahde. 2007. Reproductive ecology of Vipera latastei, in the Iberian Peninsula: Implications for the conservation of a Mediterranean viper. Zoology 110: 9-19.

Pinto, R. R. and R. Fernandes. 2004. Reproductive biology and diet of Liophis poecilogyrus poecilogyrus (Serpentes: Colubridae) from southeastern Brazil. Phyllomedusa 3: 9-14.

Pinto R. R., O. A. V. Marques, and R. Fernandes. 2010. Reproductive biology of two sympatric colubrid snakes, Chironius flavolineatus and Chironius quadricarinatus, from the Brazilian Cerrado domain. Amphibia-Reptilia 31: 463-473.
Pizzatto, L. and O. A. V. Marques. 2002. Reproductive biology of the false coral snake Oxyrhopus guibei (Colubridae) from southeastern Brazil. AmphibiaReptilia 23: 495-504.

Ripa, D. 1994. The reproduction of the Central American Bushmasters (Lachesis muta melanocephala and Lachesis muta stenophrys) for the first time in captivity. Vivarium 5: 36-37.

Ripa, D. 2004. The Bushmasters (Genus Lachesis Daudin, 1803): Morfology in Evolution and Behaviour. CDROM. Wilmington, Ripa Ecologica.

Roeder, M. 1975. Diagnóstico sócio-econômico da região cacaueira. Vol. 4. Reconhecimento climatológico. Ilhéus. Convênio IICA/CEPLAC. 89 pp.

Sá, D. F., H. A. Almeida, I. F. Silva, and A. C. Leão. 1987. Fatores edafo-climáticos seletivos ao zoneamento da cacauicultura. Revista Theobroma 12: 169-186.

Saint-Girons, H. 1982. Reproductive cycles of male snakes and their relationships with climate and female reproductive cycles. Herpetologica 38: 5-16.

Schuett, G. W. 1992. Is long-term sperm storage an important component of the reproductive biology of temperate pitvipers? Pp. 169-184 in J. A. Campbell and E. D. Brodie Jr. (eds.), Biology of the Pitvipers. Austin. Selva.

Shine, R. 1977a. Reproduction in Australian elapid snakes II. Female reproductive cycles. Australian Journal of Zoology 25: 655-666.

Shine, R. 1977b. Reproduction in Australian elapid snakes I. Testicular cycles and mating seasons. Australian Journal of Zoology 25: 647-653.

Shine, R. 1978. Sexual size dimorphism and male combat in snakes. Oecologia 33: 269-277.

Shine, R. 1980. Comparative ecology of three Australian snake species of the genus Cacophis. Copeia 1980: 831838.

Shine, R. 1982. Ecology of the Australian elapid snake Echiopsis curta. Journal of Herpetology 16: 388-393.

Shine, R. 1987. Food habits and reproductive biology of Australian snakes of the genus Hemiaspis (Elapidae). Journal of Herpetology 21: 71-74.

Shine, R. 1994. Sexual size dimorphism in snakes revisited. Copeia 1994: 326-345.

Shine, R. 2003. Reproductive strategies in snakes. Proceedings of the Royal Society of London B 270: 9951004. 
Souza, R. C. G. 2007. Reproduction of the Atlantic Bushmaster (Lachesis muta rhombeata) for the first time in captivity. Bulletin of the Chicago Herpetological Society 47: 41-43.

Solórzano, A. and L. Cerdas. 1986. A new subspecies of the bushmaster, Lachesis muta, from southeastern Costa Rica. Journal of Herpetology 20: 463-466.

Solórzano, A. and L. Cerdas. 1989. Reproductive biology and distribution of the terciopelo, Bothrops asper Garman (Serpentes: Viperidae) in Costa Rica. Herpetologica 45: 444-450.
Vial, J. L. and J. M. Jimenez-Porras. 1967. The ecogography of the bushmaster, Lachesis muta, Central America. American Midland Naturalist 78: 182-187.

Vitt, L. J.and L. D. Vangilder. 1983. Ecology of a snake community in Northeastern Brazil. Amphibia-Reptilia 4: 273-296.

Zug, G. R., B. S. Hedges, and S. Sunkel. 1979. Variation in reproductive parameters of three Neotropical snakes, Coniophanes fissidens, Dipsas catesbyi and Imantodes cenchoa. Smithsonian Contributions in Zoology 300: $1-20$.

Appendix I. Specimens examined.

Arataca (MZUESC 2162-63, 4263), Camacã (CZGB 5656, MZUESC 4395), Camamu (CZGB 1030, 1276, 2965, 4524, 5442-43, 6669, 7349, 7802, 8040, 8658-59, 9318, MZUESC 314, 325, 327, 619, 622, 625, 1081, 1402, 1404-05, 1407, 1533-34, 3011-12, 3724, 4859), Ibicarai (CZGB 5359, MZUESC 299, 1053), Ibirataia (CZGB 8538), Igrapiúna (MZUESC 3941), Ilhéus (CZGB 262, 276, 402, 1157, 1741, 2069, 2084, 2085, 2319, 2669, 2684, 2845, 2913, 2916, 3026, 3068. 3031, 3123, 3971, 3955, 3991, 4071, 4096, 4550, 4553, 4648, 5029, 5174, 5599, 6198, 6603, 7344, 7585, 9313, 9355, MZUESC 110, 618, 710-11, 1210, 1402, 2001, 2575, 2683-85, 3717, 3794, 3797, 4055, 4094, 7344), Itacaré (CZGB 288, 550, 1603, 3316, 4321, 6149, MZUESC 3917-18, 3936), Itapebi (MZUESC 778), Itamaraju (CZGB 9107), Ituberá (CZGB 7354, 7429-30, 7431, 7803, 8400, 8041, 9356, MZUESC 1079-80, 1429, 3013-15), Medicilândia (CZGB 3068), Mutuípe (MZUESC 1472, 2968-69), Porto Seguro (CZGB 3689), Una (CZGB 1528, 4617, MZUESC 536), Uruçuca (CZGB 1128), Valença (CZGB 1138, 1203, 1714, 3850).

Editor: Kate Jackson 